\title{
Article
}

\section{Green Light for Adaptive Policies on the Colorado River}

\author{
John Fleck 1,2,* and Anne Castle ${ }^{3}$ \\ 1 Utton Transboundary Resources Center, University of New Mexico School of Law, Albuquerque, NM 87131, USA \\ 2 Department of Economics and Water Resources Program, University of New Mexico, Albuquerque, NM 87131, USA \\ 3 Getches-Wilkinson Center for Natural Resources, Energy and the Environment, University of Colorado Law \\ School, Boulder, CO 80309, USA; annejcastle@gmail.com \\ * Correspondence: fleckj@unm.edu
}

\section{check for}

Citation: Fleck, J.; Castle, A. Green Light for Adaptive Policies on the Colorado River. Water 2022, 14, 2. https://doi.org/10.3390/w14010002

Academic Editor: Brian Richter

Received: 4 November 2021

Accepted: 14 December 2021

Published: 21 December 2021

Publisher's Note: MDPI stays neutral with regard to jurisdictional claims in published maps and institutional affiliations.

Copyright: (C) 2021 by the authors. Licensee MDPI, Basel, Switzerland. This article is an open access article distributed under the terms and conditions of the Creative Commons Attribution (CC BY) license (https:// creativecommons.org/licenses/by/ $4.0 /)$.

\begin{abstract}
The Colorado River is a critical source of water supply for 40 million people in nine states spanning two nations in western North America. Overallocated in the 20th century, its problems have been compounded by climate change in the 21st century. We review the basin's hydrologic and water management history in order to identify opportunities for adaptive governance to respond to the challenge of reduced system flows and distill the ingredients of past successes. While significant advances have been made in the first two decades of the 21st century, these past actions have not been sufficient to halt the declines in the basin's reservoirs. We find that the mix of federal, state, and local responsibility creates challenges for adaptation but that progress can be made through a combination of detailed policy option development followed by quick action at hydrologically driven moments of opportunity. The role of directives and deadlines from federal authorities in facilitating difficult compromises is noted. The current state of dramatically decreased overall flows has opened a window of opportunity for the adoption of water management actions that move the river system toward sustainability. Specific measures, based on the existing institutional framework and on policy proposals that have circulated within the Colorado River community, are suggested.
\end{abstract}

Keywords: water scarcity; water shortages; water budgets; water laws and policies; Colorado River

\section{Introduction}

The year 2021 witnessed unprecedented water supply challenges on the Colorado River and the institutional reactions hardwired to meet those challenges. On the water supply side, the reservoirs behind the river's two largest dams-including Hoover Dam, the icon of a generation of such facilities capable of reconfiguring entire river basins-dropped to the lowest levels since they were built in the 20th century [1]. Institutionally, the U.S. federal government made the river's first formal "shortage" declaration, flipping the "on" switch to trigger the first of what appeared likely to be an escalating series of pre-planned reductions in consumptive water use indexed to water levels in the declining Lake Mead [2]. Communities that depend on the river's water, especially farmers and cities in the U.S. state of Arizona, girded for cuts in the available supply in 2022 and engaged in feverish discussion about the risks of deeper cuts to come [3].

Media attention was frenzied. Publications ranging from The New Yorker [4] to the Christian Science Monitor [5] to Landscape Architecture Magazine [6] and broadcasts from The Late Show [7] to VICE News [8] awoke to the concerns with the reliability of the water supply for 40 million people in two countries. The primary theme was the current "drought" and its impacts on immediate supplies, with a nod to the future climate-changeinfluenced predictions of lower flows. While the term "drought" is widely used and generally understood, it may be misleading in its implication that the drought condition is a temporary one. Colorado River scientists have suggested that the term "aridification" is more accurate in describing the river's increasingly water scarce environment [9]. However, while general audiences are hearing about the river's troubles for perhaps the first time, 
the seeds of today's conditions were planted decades ago and are well known to basin water managers.

The impact of the formal shortage declaration represented an institutional successimplementation of a climate change adaptation plan developed collaboratively by federal governments in two nations, state governments, local water agencies, tribes, and nongovernmental organizations over the previous fifteen years. However, the extraordinary and rapid decline of the river system's reservoirs also suggests that the river management community's response thus far has significant shortcomings that must be addressed [10,11].

The Colorado River Basin's problems are twofold. First, decisions made a century ago overallocated the river's water, promising more to the region's farms and growing cities than the river, even under a stationary climate subject to decadal-scale variability, could deliver [12]. Adapting the institutional framework-reducing supplies to communities that became reliant on those unrealistically large supply estimates-has proven a challenge, in part because there is limited centralized authority and longstanding norms constraining its use, and changes must be painstakingly negotiated among multiple parties. Second, climate change has magnified the problem-21st century flows are $20 \%$ below the already inadequate 20th century average, with a substantial portion of that reduction attributed to climate change, and continued declines are predicted [13-15]. Despite the steps already taken, annual consumptive use of water exceeded annual supply by an average of 1.1 million acre feet (approximately 1.4 billion cubic meters-hereafter abbreviated "bcm") per year in the decade ending in 2021 (based on total reduction in end-of-September reservoir levels) [16].

There is extensive Colorado River literature in three major areas: (a) hydrologic and climate science explaining past flows and projecting future changes as a result of greenhouse-gas driven changes to the climate; (b) legal scholarship on the agreements, statutes and court decisions that create the framework for water allocation (rules governing how much each state is entitled to consume) and distribution known as the "Law of the River"; and (c) social science literature examining the functioning of the decision-making processes $[13,14,17,18]$. Our work aims to bridge the gaps among these three threads and better understand how they interweave through an analysis of the processes through which water management structures in the Colorado River basin have come together over the last three decades. Our motivation is to inform decision-making processes going forward and to better assist the river management community in making the difficult decisions to come.

Our work comes with a significant limitation. The analysis presumes a continuation of the basic structure and function of current water management institutions at the local, state, national, and international level. By "institutions," we mean both the rules embodied in the "Law of the River" and various related state water management rules and regulations, and the government agencies that carry them out. We do not consider the creation of new alternative structures (for example, the possibility of the creation of a new River Basin Commission, as has been suggested by some commentators) [18]. The possible implementation of such large-scale institutional change is beyond the scope of this work.

Political scientist John W. Kingdon suggests that thorny problems can be solved only when there is a convergence of political will and available solutions [19]. Political will may be a fleeting phenomenon; solutions need time to develop and mature. Accordingly, solution sets must be crafted and refined over time and be available to be seized upon when the political will to adopt them is present. Applied to the Colorado River, this framework suggests that potential management solutions must be proposed and sharpened up over a period of years, at the ready for championing and implementation when political winds are favorable.

\section{Background}

The Colorado River drains a watershed spanning a quarter of a million square miles $(\sim 650,000$ square $\mathrm{km})$ in the United States and Mexico (see Figure 1$)$. In addition to serving populous and important urban communities, the Colorado provides all or part of the 
water for 5 million acres ( 2 million hectares) of irrigated farmland in nine states across two countries, a centerpiece of economy and culture across a vast reach of rural western North America $[20,21]$.

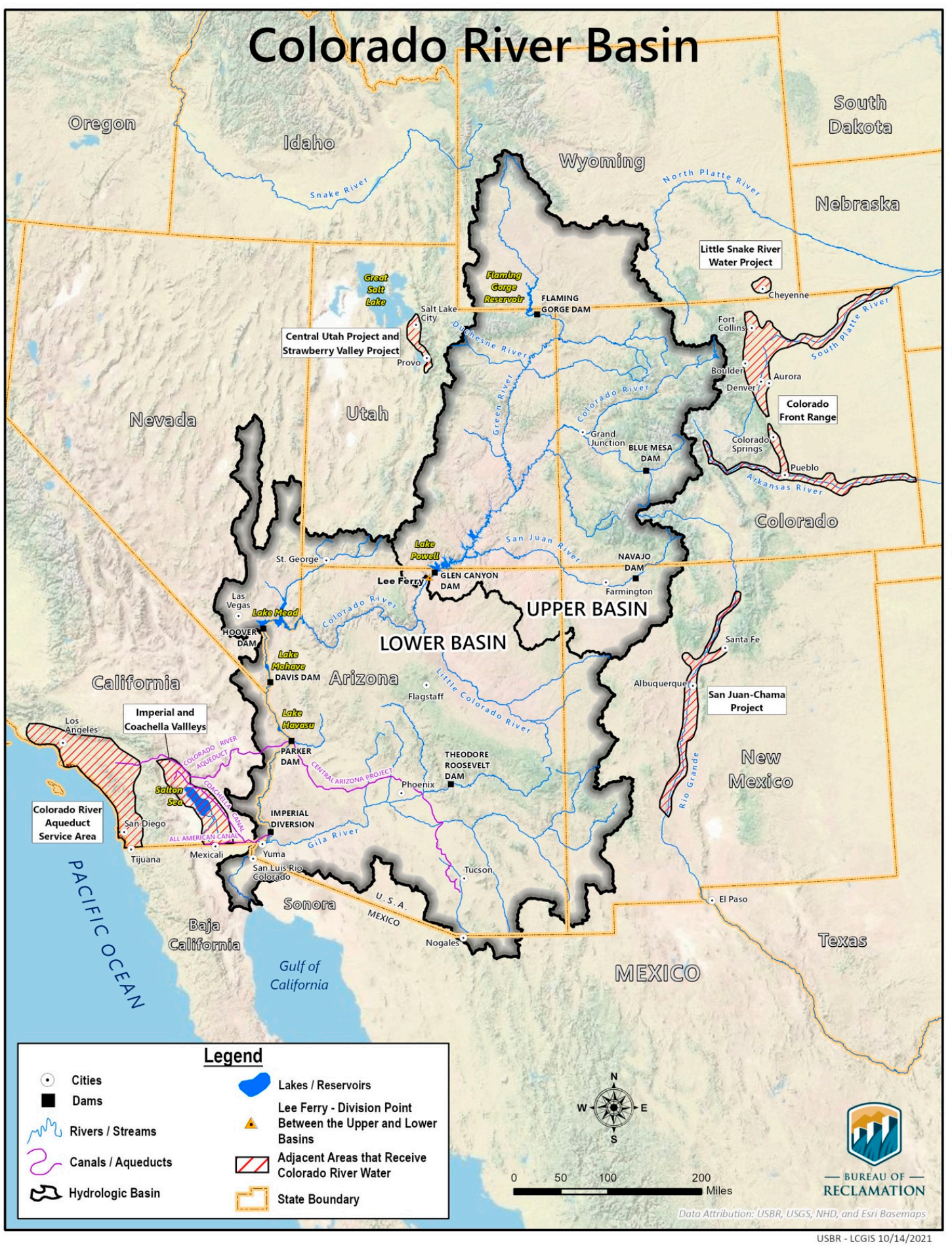

Figure 1. Colorado River Basin. U.S. Bureau of Reclamation.

Similarly to many semi-arid region rivers, the Colorado's annual flow is highly variable [22]. This resulted in efforts across the 20th century to build major dams on the river that are capable of protecting downstream farming valleys from flooding, capable of capturing the spring snowmelt runoff peak flows for use during late summer dry season, and storing water during wet years for use in dry years. The river's two largest reservoirs, 
Lake Mead and Lake Powell, can store roughly four times the river's annual flow, which is the largest storage ratio of any major river in North America [23,24].

\subsection{Recent Hydrologic Conditions}

The 20 percent reduction in river flows in the current century has caused a corresponding but even more precipitous decline in the major reservoirs [15]. Both starting the century at 95 percent full, Lake Powell has dropped to 29 percent and Lake Mead to 34 percent capacity as of early December $2021[25,26]$.

The reservoirs' declines have come despite significant reductions in water use among U.S. users in the Lower Colorado River Basin (in the states of Arizona, California, and Nevada), while Upper Basin users (in the states of Colorado, New Mexico, Utah, and Wyoming) have never expanded into their full legal allocation. The basin's water accounting is hampered by uncertainties and gaps in a number of areas, including accurate estimates of evaporation from some major reservoirs, volume of use of tributary water within the river's Lower Basin region, and questions concerning the methodology for estimating consumptive use $[27,28]$; but the best available data suggest water use in the basin is declining. The 1922 Colorado River Compact and subsequent statutes and court decisions allocated 7.5 million acre feet $(9.3 \mathrm{bcm})$ of water each from the Colorado's main stem for the river's Upper and Lower Basins. From 2011 to 2020, Lower Basin mainstem use averaged 7.2 million acre feet $(8.9 \mathrm{bcm})$ of water, while the Upper Basin from 2009 to 2018 averaged 3.9 million acre feet $(4.8 \mathrm{bcm})$ [29,30]. (Differing time periods were chosen in order to use the most recently published data for each area of the basin. Neither dataset includes evaporation calculations. It should be noted that there are several different methods of calculating consumptive use of water and that the U.S. Bureau of Reclamation's calculations, on which these numbers are based, are not uniformly accepted by the Colorado River Basin States [31].)

Despite users taking less than their full legal allocations, the major reservoirs have continued to decline across the 21st century because of a fundamental mismatch between the 20th century expectations of what the river can provide and the 21st century reality (see Figure 2). In September 2021, the U.S. Bureau of Reclamation projected a 41 percent chance based on recent hydrologic conditions that Lake Mead could drop to less than one quarter full by 2025 and a 47 percent chance that Lake Powell could drop below the target level for ensuring continued safe hydropower generation as soon as 2023 [32]. It is also important to note that many tribal water rights in the basin have not yet been fully developed but will likely be in the future, placing additional stress and uncertainty on an already over-allocated system [33]. Moreover, environmental and ecosystems needs have not been historically accounted for as part of the overall system's water balance [34].

Combined Storage, Lakes Mead and Powell

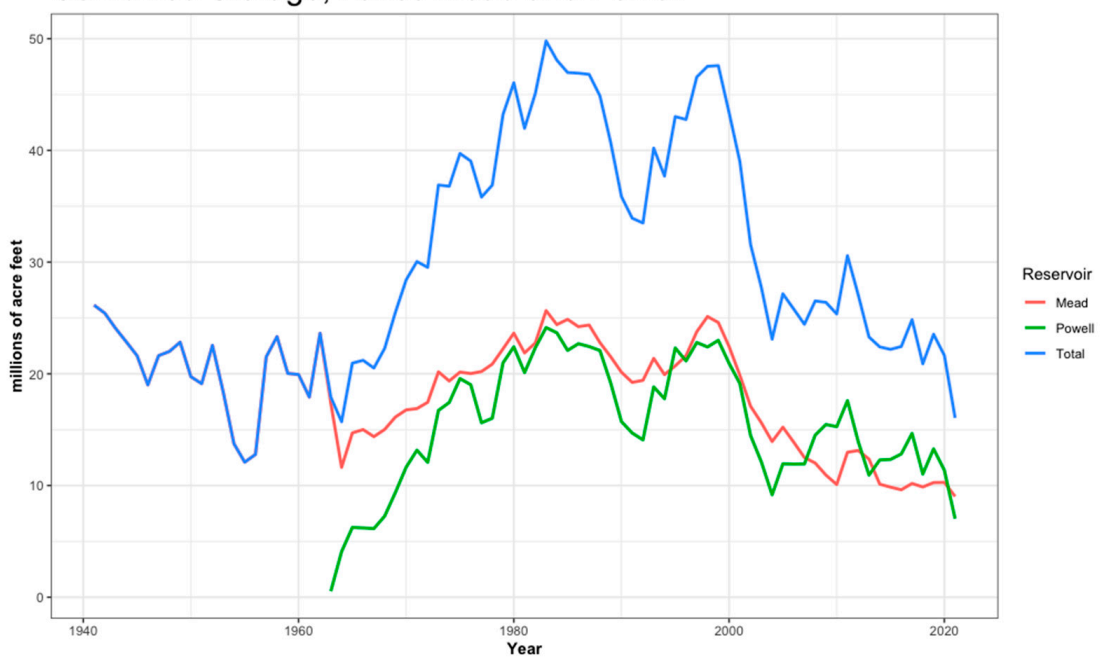

Figure 2. Total Storage in Lakes Mead and Powell. Data: U.S. Bureau of Reclamation. 


\subsection{Hydropower Production}

Hydropower generation has been and continues to be an important element of the Colorado River system of dams and reservoirs. This system can supply approximately 4200 megawatts of energy annually, reducing the use of fossil fuels in the area [23]. The value of the hydropower produced at Glen Canyon Dam (the structure that creates Lake Powell) alone has been estimated to average over \$150 million annually [35]. However, hydropower production at Glen Canyon Dam has decreased by approximately $16 \%$ since the year 2000 and further decreases across the system are anticipated as a result of lower inflows and releases [36]. The loss of these revenues ripples through many different sectors as power revenues support the operation of other reclamation water projects and environmental programs (e.g., endangered fish recovery, adaptive management of critical areas, and salinity control) [37]. In addition, the reduced availability of low-cost, renewable hydropower requires the federal Western Area Power Administration to purchase power from other higher cost sources to meet its contractual obligations, resulting in very significant cost hikes to utilities and their customers $[38,39]$.

\subsection{Climate Scientists' Predictions}

The first climate change projections for reductions in the Colorado River's flows as a result of a warming climate date back to 1983, when climate scientists projected that a 2-degree Celsius rise in temperatures would reduce the Colorado River's annual flow by nearly 4 million acre feet $(4.9 \mathrm{bcm})$ [40]. Since then, ever-more refined research has supported the basic direction and scale of their work, with recent analysis suggesting that warming temperatures are responsible for a substantial fraction of the current decline in the river's flow and that basin water users should expect a 9 percent decline in the river's flow for every additional $1{ }^{\circ} \mathrm{C}$ of warming [41].

The result is a situation that is dire but that was entirely predictable. As early as the 1990s, even before the effects of climate change had become noticeable, leaders of the Colorado River water management community recognized and began wrestling with the coming imbalance between water supply and use [42]. In the decades since those first efforts, Colorado River basin water managers have been engaged in what amounts to a process of continuous negotiation over how to adjust the river's water allocation and operation rules in response to the apparent problem, a project that remains fundamentally incomplete [43].

\subsection{Implications}

On the water supply side, the river's users face two problems. First, 20th century expectations used as the premise for development of the dams and distribution systems were based on overestimates of the river's available supply [44]. Thus, even without climate change, the reservoirs would likely be declining as water use outstrips supply. However, the imbalance is exacerbated by the already experienced climate change-driven declines in the 21st century and the risks of substantial further flow reductions [13-15,41].

On the institutional side, the river's users are faced with a classic example of "polycentric governance," with "many centers of decision-making which are formally independent of each other" [45]. By "governance", we mean a set of processes that extend beyond the specific actions of government agency actors to include the critical role of non-government actors, as well as informal norms - the "process by which the repertoire of rules, norms, and strategies that guide behavior within a given realm of policy interactions" are "formed, applied, interpreted, and reformed" [46]. As applied to the Colorado River, the structure of governance evolved across the 20th century with the U.S. national government active in the funding and construction of dams and other infrastructure, but within a federalist structure that left much water management control in the hands of state and local governments [47]. Commentators have described this in the case of the Colorado River Basin as "a decentralized and fragmented governance system: a complex web of disjointed and piecemeal authorities and institutions inform the allocation and use of water with no single venue to deal comprehensively with Colorado River Basin issues [48]." There is no central 
administrative entity with the authority to impose basin-scale solution, and what limited authority the federal government does have is strongly constrained by a community norm against its use [49].

\section{Methodology}

We have approached this research by combining the best available data on the river's water supply and use with an analysis of historical accounts, government decision documents, meeting records, and contemporary news media accounts concerning the various decision-making processes from the last decades. By "supply" we mean both the annual input of river flow into the system and the available storage at any given time. Storage is a particularly important metric for two reasons. First, it reflects the system's mass balance-the difference between the amount of water provided by weather and climate and the amount consumed by various users. Second, it provides a buffer against variability - the ability to consume more water in a given year than the river provides in that year.

For water supply and use, we rely on the following:

- Reservoir storage and related data for Lake Powell from the completion of construction in 1963 to the present [50] and Lake Mead from the completion of construction in 1935 to the present [51];

- Estimates of flows on the river dating to 1906, the earliest point in time for which detailed river flow data are available [52];

- $\quad$ Estimates of consumptive water use for the Upper Colorado River Basin from 1971, when reporting began, to the present [30] and the Lower Colorado River Basin from 1964 [29,53].

By combining this water supply and use data with the historic record, we evaluate past and present Colorado River governance in terms of the following criteria [54,55]:

- Cooperation and collaboration - the ability to prevent legal conflict while involving the full range of governmental and non-governmental communities impacted by the river;

- Sustainability - the ability to set and meet water allocation and use goals that ensure the continued viability and prosperity of the communities using the river's water, address ecosystem needs, and balance the equities of various interests.

\section{Discussion}

The interplay between the river's hydrologic and institutional history demonstrates that appropriate adaptive tools exist and have been used well in the past. Our review of the historical record suggests that, while conflict has often accompanied difficult discussions, large-scale litigation once common in the basin has largely been avoided for more than a half century. In addition, the range of stakeholders included in decision making has continued to broaden as the river community accepts and incorporates changing values around the river's use, including environmental benefits and social justice equities particularly in connection with the interests of Native American tribes [55]. However, recent events suggest the scale of the challenge is growing and the time available for the effective use of these tools is running short. The available solution set should be honed to areas that can be readily implemented by public officials.

\subsection{Our Key Findings}

- Past negotiated reductions in water allocation have succeeded in diminishing consumptive water use, slowing reservoir declines, and largely avoiding litigation. Within communities impacted by those negotiated reductions, local water users have been successful in adapting to their smaller supplies. However, these actions have proven insufficient as a response to the very low flows that are becoming the new normal.

- $\quad$ Successful completion of such negotiated agreements tends to be triggered by very dry conditions, which open a window of opportunity for agreement on water management steps that would otherwise be unpalatable, regardless of how valuable those steps 
might be in the long run. Federal directives and deadlines have also played an important role.

- Future action plans, in the form of negotiated agreements and communities' response to changing allocations, must incorporate the need to operate under conditions of growing uncertainty about the river's flow, including flow scenarios lower than experienced in the past.

- Operating plans and negotiated allocation rules must recognize the fundamental imbalance between current supply and consumptive water use.

- The water rights and claims of indigenous communities and the need for environmental flows must be incorporated into river management decision making even as other users plan for reduced allocations. These needs have been omitted from past allocation and management plans but are gaining recognition as values that must be accommodated going forward [55].

\subsection{Past Successful Management Adjustments}

The constraints on Colorado River supply and its relationship to demand have been apparent for decades and water managers in the basin have been faced with decisions about how to react. Individual communities, when threatened with less water at the local level, have demonstrated success at reducing their use when available supplies are curtailed [56]. The challenge we focus on here is managing the necessary changes in water allocation at the basin scale in order to bring those allocations for communities depending on the river into balance with the river's available supply. The difficulty of securing an agreement of seven U.S. states and two countries on a river management strategy, especially in the face of near certain required reductions in water usage, cannot be overstated. However, a review of the actions taken over the past two decades, compared with resulting water use reductions, suggests negotiations have been conducted successfully in the Colorado River Basin. The actions follow the pattern suggested by Kingdon-political attention lurching to an issue, enabling action on policy proposals that had been developed previously and were at the ready when the situation was viewed as sufficiently problematic for a window of policy action opportunity to open $[19,57]$. Looking at the common themes in those previous agreements and the circumstances of their completion is helpful in understanding the necessary conditions for accomplishment in the present crisis.

We evaluate the three 21st century agreements through which allocations of water for consumptive use were revised. These examples of effective collaboration and agreement around river operations include the 2007 Interim Guidelines, the series of 21st century agreements with Mexico that provide additional operational detail for the 1944 Colorado River Treaty between the U.S. and Mexico, and the Drought Contingency Plan of 2019. Each of these pacts addressed diminished supplies in the Basin. Together, they suggest a navigable path forward.

\subsubsection{Interim Guidelines}

The 2007 Interim Guidelines were the first set of formal rules for reducing water allocations as supplies ran short. They arose from a recognition that drought conditions and continued heavy water use in the Basin were rapidly depleting stored water supplies in Lake Mead. The initial trigger came at the height of the 2002 drought, the worst inflow year in recorded history. Pursuant to the Interim Surplus Guidelines [58], adopted by the Department of the Interior in 2001, and agreed to by the Basin States (Arizona, California, Colorado, Nevada, New Mexico, Utah, and Wyoming), California water users were expected to enter into a "Quantification Settlement Agreement" or QSA that would provide gradual reductions in California's water usage in excess of its allocated 4.4 million acre feet $(5.4 \mathrm{bcm})$. The deadline for entering into this agreement was established as 31 December 2002.

At a meeting of the Colorado River Water Users Association in mid-December 2002, Secretary of the Interior Gale Norton warned that California's deliveries would be reduced 
unilaterally by the Interior unless QSA was executed by the end of the year [59]. In fact, however, the Lower Basin states were not able to reach an agreement by the deadline, and surplus water that had previously been available to California water users was cut off. Deliveries to California water users were abruptly limited to 4.4 million acre feet $(5.4 \mathrm{bcm})$ in 2003, a reduction of approximately 800,000 acre feet $(1 \mathrm{bcm})$ from previous levels. Importantly for the future of water agreements in the basin, despite predictions of doom, California absorbed the reductions with only modest impact [43].

The California parties were finally able to come to agreement in 2003 and executed the Colorado River Water Delivery Agreement, which included the concepts in the QSA [60]. Crucially, the aforementioned steps-the Interim Surplus Guidelines and the QSA-did not arise quickly but rather were the result of more than a decade of discussion among the parties of possible policy actions. Those policy measures, thus, were fleshed out and available as the dry conditions of the early 2000s opened a policy window, creating the opportunity for action [42].

However, the drought persisted and again, in 2004, Interior officials warned that cutbacks in deliveries would be imposed unless the Basin States agreed to a drought management plan on their own. In 2005, the Secretary of the Interior directed Reclamation to develop additional Colorado River management strategies to address operations of Lake Powell and Lake Mead under low reservoir conditions. After much discussion, haggling, and evaluation of alternatives, the Colorado River Interim Guidelines for Lower Basin Shortages and the Coordinated Operations for Lake Powell and Lake Mead (Interim Guidelines) were adopted in 2007 [61].

Results: Water deliveries to the key users impacted by these changes, the Lower Basin states, declined by 22 percent between 2002, the last year prior to the first of the institutional changes, and 2020 [29]. While Lake Mead continued to drop during this time period, the array of conservation measures lessened the impact, raising Lake Mead's surface elevation at the end of 2020 by 36.5 feet compared to the level it would have reached absent the measures (2020 accounting report [29]). Large scale litigation was avoided, although the threat of litigation by the federal government against allegedly "inefficient" water use by California farmers loomed as California negotiated the final agreements to reduce its water use [62].

\subsubsection{Agreements with Mexico}

During the 21st century, the relationship between the United States and Mexico with respect to management of the Colorado River has evolved from bitter controversy and litigation to substantial collaboration. Two decades after the execution of the treaty between the U.S. and Mexico in 1944 [63], concerns began to arise about the quality of water being delivered to Mexico, specifically the increasing salinity content. The problem escalated in the early 1960s when the Wellton-Mohawk Irrigation and Drainage District in Arizona began groundwater pumping to lower the high water table in the area and delivering the highly saline drainage waters to the river [64]. This practice coincided with a dramatic decrease in the overall amount of water delivered to Mexico because of the filling of Lake Powell [64]. After years of negotiations without resolution, President Nixon issued a communiqué directing his representatives to find a "permanent, definitive and just" solution for submittal to the Mexican president [65]. Subsequently, National Security Advisor Henry Kissinger provided additional direction to the U.S. negotiators to protect Mexico from the effects of the salty Wellton-Mohawk drainage [66]. Minute 242, signed in 1973 , ultimately resolved controversy by tying the quality of water delivered to Mexico to the quality of the delivery at Imperial Dam in the U.S. [67].

Subsequent challenges in U.S./Mexico relations on the river were focused more on water quantity. The concrete lining of the All-American Canal and resulting elimination of considerable ground water recharge in Mexico border lands generated significant hostility between the countries and litigation in U.S. federal court. However, a natural disaster, a major and devastating earthquake in northern Baja California in 2010, instigated col- 
laborative discussions between the two countries and resulted in an agreement allowing Mexico to defer delivery of some of its Colorado River water and store that water in Lake Mead [68,69]. Importantly, the triggering crisis—-the earthquake that restricted Mexico's ability to use its Colorado River allocation-was preceded by more than a decade of quiet policy proposal development. In addition, the International Boundary and Water Commission (IBWC) - the binational body directed by the 1944 Treaty between the U.S. and Mexico to administer the rights and responsibilities of both countries in the Colorado River and to settle disputes [63] — provided a focal point for dialogue and agreement. When the crisis hit and decision-makers' attention lurched to the issue, the policy proposals and the forum for discussion were ready. Following that success, a series of new minutes was negotiated, addressing the sharing of the burden of low flows in the system, providing for cooperative efforts to restore flows to the lower river and the delta and for joint infrastructure projects, and allowing Mexico to store conserved water in Lake Mead for future use [43].

Results: The Colorado River Delta pulse flow in 2014 provided the first intentional delivery of environmental water for the dry river delta. Mexico used its new storage capacity in Lake Mead to help manage its own water and to help U.S. water users: At the end of 2020, Mexican stored reserves in Lake Mead that totaled 200,000 acre feet $(0.25 \mathrm{bcm})$, which was enough to raise the reservoir's elevation by 2.5 feet at current elevation levels (final 2020 accounting report [29]).

\subsubsection{Drought Contingency Plans}

Continuation of low flows in the river system in the second decade of the 21st century resulted in the realization that the accommodations made in the 2007 Guidelines and agreements with Mexico were insufficient to balance supply with demand. In 2013, Secretary of the Interior Sally Jewell urged the states to take immediate action and come up with a contingency plan to address the potential for lower flows caused by climate change [70]. Referencing her predecessors, she said that she would not ignore her responsibility "to act if conditions worsen and if the states can't reach consensus on contingency actions [70]."

The state parties worked hard and continuously for the better part of five years to come together around a plan that would address the imbalance and worsening hydrologic conditions. However, by the end of 2018, while many component parts of the plan had consensus, there was still no final deal. The remaining hurdles were not disagreements about the basic components but rather the intrastate allocation of reduced supplies and desired commitments for environmental restoration efforts.

During 2018, Lake Powell dropped significantly, but the water levels in Lake Mead remained relatively stable [71]; water leaders in Arizona-the key holdout in approving the deal—saw fewer reasons for quick action [72]. The Commissioner of Reclamation Brenda Burman then warned that if the plans were not completed by 31 January 2019, the Department of the Interior would adopt a course of action prior to the following August [73]. Shortly thereafter, the seven Basin States and the Department of the Interior agreed to a series of measures known as the Drought Contingency Plan or DCP that was intended "to provide additional security and certainty in the water supply of the Colorado River System for the benefit of the people served by [the System] [74]."

Separate plans were put in place for the Upper and Lower Basins. The Lower Basin plan included additional conservation of water by the states with the resulting savings stored in Lake Mead and enhancement of flexibility in recovering previously stored water. The Upper Basin plan provided for use of upstream reservoir releases to maintain critical levels in Lake Powell and the foundation for a demand management or conservation program in the Upper Basin [74].

For the first time, certain tribes in Arizona were involved in the intrastate DCP discussions and two tribes, the Gila River Indian Community and the Colorado River Indian Tribes, reached agreement with the state and the federal agencies to participate directly in water management arrangements. These agreements provided compensation to the tribes for using less of their substantial water rights allocations and redirecting that water to 
assist other Arizona water users facing shortage [75,76]. All DCP agreements are in effect for the interim period of the 2007 Guidelines or until 31 December 2025 [74]. While recognizing the unparalleled nature of the agreements and commitments in the DCP, virtually all of the parties involved acknowledged that the measures included were insufficient to provide adequate response to climatological conditions expected in the mid-term to long-term future [77].

Results: Water allocations to Lower Basin users were reduced in 2021 and 2022 under the agreement, and the Secretary, under the emergency powers described in the DCP, began releasing water from upstream reservoirs to Lake Powell to reduce risk to power production in July $2021[78,79]$. Certain Native American tribes were substantively involved in state water management discussions and were, in fact, vital to the State of Arizona's ability to accommodate the delivery reductions contemplated by the Lower Basin DCP.

\section{Summary of Results, Suggested Actions}

Looking at past successful negotiations on Colorado River operations, it is clear that hydrologic conditions have been and will continue to be the primary driving factor in motivating the Basin States to adopt measures to reduce use and more efficiently manage the system. There has been candid acknowledgement that overall flows in the Colorado River system are declining and that average demand exceeds average supply. The back-to-back years of 2020 and 2021 have been particularly dreadful from a water availability perspective, spurring more urgency in the discussions of deeper and more systemic reductions in use. Just as the earthquake in 2010 spurred the agreements with Mexico, the devastating dryness of the last two years is providing unambiguous motivation, opening what Kingdon would call a "policy window" [19]. However, Kingdon argues that a necessary pre-condition to action when such policy windows open is the work performed ahead of time in the development of a menu of policy options. Below, we suggest what some of those might be.

The principal negotiators for the Colorado River Basin States have been assisted in the past in coming to agreement around operational measures by threats and cajoling from federal officials. Each of the historic agreements discussed above was preceded by specific direction to the states to devise a solution to the problem at hand. For the interstate agreements embodied in the 2007 Interim Guidelines and the DCP, explicit threats were made by the Department of the Interior that its leadership would take unilateral action if a jointly negotiated deal was not forthcoming. The healthy fear of an unwelcome federal takeover of river operations provides rich motivation to states to reach their own agreement. In addition, federal threats provide political cover for state officials to agree to measures that are not universally supported by their constituents (e.g., "If we didn't agree to X, the feds would order $Y$, which would be much worse!"). Federal warnings have been most effective when they establish explicit goals and deadlines, effectively making the time frame of the policy window explicit.

Finally, consensus among the state parties to a set of operational mechanisms has been an obvious key component of successful management of the river. The absence of agreement by one of the seven Basin States, or even one of the major water users, has delayed a basin-wide resolution in the past or caused a re-jiggering of responsibilities, which can postpone implementation, trigger additional dissension, and increase the possibility of litigation [80-82]. The ongoing relationships among the relevant state and federal principals has played a significant role in allowing closure on operational agreements in the past and will continue to do so. Major water users in the basin have also commonly been included in some form in negotiations or behind-the-scenes discussions. The recognition of the significant water holdings and interests of basin tribes in river management makes it imperative that the same type of relationships be established and that tribal voices are included in these conversations. The lack of a formal, organized forum for Colorado River stakeholder discussions and dispute resolution within the U.S., similar to the IBWC for binational issues, has not appeared to hinder progress on operational adjustments in the 
past but can result in marginalization of non-governmental actors unless affirmative efforts are undertaken by state and federal representatives to insure inclusion [43].

\section{Potential Federal Actions}

Even though a collective agreement among the federal government, states, and other stakeholders on operational actions is greatly preferred, the swiftness of the declines in available flows and reservoir storage and the internal political dynamics within the Basin States may make unilateral actions by the Department of the Interior necessary. This dynamic has recently played out in the drought response operations of the Colorado River System Project reservoirs upstream from Lake Powell, sending water downstream to protect critical levels, adopted through the Secretary's emergency powers. Examples of actions that the Secretary could take unilaterally are listed in Table 1.

Table 1. Possible near-term unilateral federal actions (for details, see Supplemental Materials Table S1).

\begin{tabular}{ll}
\hline \multicolumn{1}{c}{ Action } & Result \\
\hline $\begin{array}{l}\text { Account for Lower Basin reservoir evaporation as a } \\
\text { reduction in water available for delivery }\end{array}$ & Water use reduction \\
\hline Account for water ordered but not diverted & $\begin{array}{l}\text { Reduction in deliveries not counted against contract } \\
\text { requirements but borne by the overall system }\end{array}$ \\
\hline $\begin{array}{l}\text { Authorize additional or expanded storage credit } \\
\text { account volumes in Lake Mead }\end{array}$ & Incentivize conservation \\
\hline
\end{tabular}

Formation of a sovereign advisory committee, acknowledging both states and tribes as sovereigns, for surfacing, discussing, and negotiating

Expanding stakeholder representation tribal issues

The Secretary and her representatives can also play a valuable role in suggesting to the Basin States the types of actions that could be beneficial to the Colorado River system as a whole and address the impacts of climate change. These suggestions would be intended as elements of post-2025 guidelines for the operation and management of the river. Examples appear in Table 2.

Table 2. Possible actions that require state concurrence (for details, see Supplemental Materials Table S2).

\begin{tabular}{|c|c|}
\hline Action & Result \\
\hline $\begin{array}{l}\text { Limits on new Upper Basin water development to } \\
\text { reduce stress on overallocated system }\end{array}$ & Reduction in growth of consumptive use \\
\hline $\begin{array}{l}\text { Measure and account for Lower Basin uses of } \\
\text { tributary water }\end{array}$ & Reduction in current use \\
\hline $\begin{array}{l}\text { Negotiated reductions in usage in all seven Basin } \\
\text { States, considering existing use levels, Compact } \\
\text { allocations, Tribal rights, and sector impacts }\end{array}$ & Reduction in current use \\
\hline $\begin{array}{l}\text { Adjustment of triggers for balancing releases from } \\
\text { Lake Powell to Lake Mead }\end{array}$ & $\begin{array}{l}\text { Guard against Upper Basin excess deliveries that } \\
\text { enable Lower Basin overuse and discourage Upper } \\
\text { Basin conservation }\end{array}$ \\
\hline $\begin{array}{l}\text { Examination of federal permit applications for } \\
\text { impact on overall water supplies, with possible } \\
\text { requirement for offsets }\end{array}$ & $\begin{array}{l}\text { Reduction in growth of total future use; integrate } \\
\text { federal decisions with water impacts }\end{array}$ \\
\hline $\begin{array}{l}\text { Federal support for augmentation through recycling } \\
\text { and desalination projects }\end{array}$ & Increase in supply \\
\hline $\begin{array}{l}\text { Implement an Upper Basin demand management } \\
\text { program [83] }\end{array}$ & Enable and incentivize conservation \\
\hline $\begin{array}{l}\text { Initiation of a process to achieve agreement on } \\
\text { measurement of consumptive use }\end{array}$ & $\begin{array}{l}\text { Enable more accurate water use accounting to result } \\
\text { in better operational control and more trust }\end{array}$ \\
\hline
\end{tabular}


Many of these concepts have been fleshed out in multi-year discussions among the parties and various papers and workshops $[11,84,85]$. This is the pre-existing policy scaffolding that can be translated quickly into adopted agreements and action.

\section{Conclusions}

The past three decades of Colorado River basin-scale water management resemble the children's game of "Red Light-Green Light." When the child designated as the "traffic light" calls out "green light," competitors are permitted to run forward toward the finish line. When the traffic light calls out "red light," they must stop. Anyone who does not stop in time is sent back to the start.

In the Colorado River Basin, climate has played the role of a traffic light. When it delivers dry years, rapidly dropping reservoirs create a "green light" condition in which attention and concern may shift the river's management from a condition to be monitored to a problem to be solved. The "red light" turns back on when a good snowpack delivers above-average flows to the reservoirs and refills depleted storage. The river game's "green lights" and "red lights" create a classic opening and closing policy window, as described by Kingdon.

This phenomenon can be seen most clearly in the transition from inaction in the 1990s to action in the early 2000s. The river's policy management community, fully aware of the possibility of future difficulties, discussed a range of potential policy actions to respond. However, full reservoirs created a "red light" condition. As the reservoirs dropped in the early 2000s, the light flashed "green," a federal mandate was issued, and important, difficult policy steps were taken.

The hydrologic conditions of 2020 and 2021, together with dwindling water storage reserves, create a "green light" opportunity. However, unlike the common traffic signal, the green lights are brief when compared to the time requirements of negotiation. A favorable water year or changes in river decision makers could cause the light to suddenly turn red. State and federal water officials should seize this opening, cognizant of its likely limited duration, and cement new agreements that steer river operations in a more sustainable direction. Well-timed and explicit federal direction may be necessary to catalyze the already ongoing discussions. Failing to capitalize on the green light now means even more depleted reservoirs and a narrowing of available options for the future.

Supplementary Materials: The following are available online at https: / www.mdpi.com/article / 10.3390/w14010002/s1, Table S1: Possible near-term unilateral federal actions, Table S2: Possible actions that require state concurrence.

Author Contributions: The authors shared equally in all phases of the manuscript's preparation. All authors have read and agreed to the published version of the manuscript.

Funding: This research received no external funding.

Institutional Review Board Statement: Not applicable.

Informed Consent Statement: Not applicable.

Data Availability Statement: Not applicable.

Conflicts of Interest: The authors declare no conflict of interest.

\section{References}

1. Runyon, L. Lake Powell—Nation's Second-Largest Reservoir-Hits Record Low. Available online: https://www.kunc.org/ environment/2021-07-24/lake-powell-nations-second-largest-reservoir-hits-record-low (accessed on 25 September 2021).

2. US Bureau of Reclamation Operation Plan for Colorado River Reservoirs, August 2021. By "consumptive use", we intend the definition the United States Supreme Court adopted in its 1963 ruling in the case of Arizona v. California, 373 U.S. 546,557 n. 23, as follows: "'Beneficial consumptive use' means consumptive use measured by diversions less return flows, for a beneficial (nonwasteful) purpose." While legal disputes over the terminology remain (see Kuhn and Fleck [12], we adopt this because it is the definition commonly used in Colorado River management today. Available online: https://www.usbr.gov/lc/region/g4000/ 24mo/2021/AUG21.pdf (accessed on 25 September 2021). 
3. The Economist, The American West Is Drying Up. Available online: https://www.economist.com/united-states/2021/08/21 /the-american-west-is-drying-up (accessed on 25 September 2021).

4. Kolbert, E. The Lost Canyon under Lake Powell. The New Yorker. Available online: https://www.newyorker.com/magazine/20 21/08/16/the-lost-canyon-under-lake-powell (accessed on 25 September 2021).

5. Kiefer, F.; Eulich, W. Water Shortage Spans the Southwest-But So Does Water Progress. Christian Science Monitor. 2021. Available online: https:/ / www.csmonitor.com/Environment/2021/0816/Water-shortage-spans-the-Southwest-but-so-doeswater-progress (accessed on 25 September 2021).

6. Viani, L.O. Landscape Architecture Magazine. September 2021. Available online: https://landscapearchitecturemagazine.org/2021 /11/09/one-big-picture (accessed on 13 December 2021).

7. The Late Show with Stephen Colbert Come Visit the Colorado River. Available online: https://www.youtube.com/watch?v= wjFztBeAJDg (accessed on 25 September 2021).

8. VICE News 40 Million People Rely on the Colorado River, and Now It's Drying Up. Available online: https:/ / www.youtube com/watch?v=5CADLfXOhkU (accessed on 25 September 2021).

9. Colorado River Research Group When Is a Drought Not a Drought? Drought, Aridification, and the "New Normal". Available online: https://www.usu.edu/colorado-river-research-group/files/crrg_aridity_report.pdf (accessed on 25 September 2021).

10. Snider, A. Drought Forces First Water Cuts on the Colorado River. They're Just the Beginning-POLITICO. Available online: https:/ / www.politico.com/news/2021/08/16/megadrought-colorado-river-505190 (accessed on 25 September 2021).

11. Wheeler, K.; Kuhn, E.; Bruckerhoff, L.; Udall, B.; Wang, J.; Gilbert, L.; Goeking, S.; Kasprak, A.; Mihalevich, B.; Neilson, B. Alternative Management Paradigms for the Future of the Colorado and Green Rivers. Cent. Colo. River Stud. White Pap. No. 6 2021, 1-85. Available online: https:/ / qcnr.usu.edu/coloradoriver/files/FS_WhitePaper_6.pdf (accessed on 13 December 2021).

12. Kuhn, E.; Fleck, J. Science Be Dammed: How Ignoring Inconvenient Science Drained the Colorado River; University of Arizona Press: Tucson, AZ, USA, 2019; ISBN 0-8165-4043-8.

13. Udall, B.; Overpeck, J. The Twenty-first Century Colorado River Hot Drought and Implications for the Future. Water Resour. Res. 2017, 53, 2404-2418. [CrossRef]

14. Woodhouse, C.A.; Pederson, G.T. Investigating Runoff Efficiency in Upper Colorado River Streamflow over Past Centuries. Water Resour. Res. 2018, 54, 286-300. [CrossRef]

15. Fleck, J.; Udall, B. Managing Colorado River Risk. Science 2021, 372, 885. Available online: https://www.science.org/doi/10.112 6/science.abj5498 (accessed on 13 December 2021). [CrossRef]

16. US Bureau of Reclamation Operation Plans for Colorado River System Reservoirs (24-Month Study). Available online: https: //www.usbr.gov/lc/region/g4000/24mo/index.html (accessed on 25 September 2021).

17. Ostrom, E. Why Do We Need to Protect Institutional Diversity? Eur. Polit. Sci. 2012, 11, 128-147. [CrossRef]

18. Kenney, D.S. River Basin Administration and the Colorado: Past Practices and Future Alternatives; The University of Arizona: Tucson, AZ, USA, 1993.

19. Kingdon, J.W. Agendas, Alternatives, and Public Policies, 2nd ed.; Longman classics in political science; Longman: New York, NY, USA, 2003; ISBN 0-321-12185-6.

20. US Bureau of Reclamation Colorado River Basin Stakeholders Moving Forward to Address Challenges Identified in the Colorado River Basin Water Supply and Demand Study. Available online: https://www.usbr.gov/lc/region/programs/crbstudy/ MovingForward/ (accessed on 25 September 2021).

21. Cohen, M.; Christian-Smith, J.; Berggren, J. Water to Supply the Land. Pac. Inst. 2013, vi.

22. Dettinger, M.D.; Diaz, H.F. Global Characteristics of Stream Flow Seasonality and Variability. J. Hydrometeorol. 2000, 1, 289-310. [CrossRef]

23. US Bureau of Reclamation 2021 SECURE Water Act Report to Congress. Available online: https://www.usbr.gov/climate/secure/ (accessed on 25 September 2021).

24. Hirsch, R.M.; Walker, J.; Day, J.; Kallio, R. The Influence of Man on Hydrologic Systems. Surf. Water Hydrol. Geol. Soc. Am. Boulder Colo. 1990, 29, 329-359, Fig 7 Tab 66 Ref 1990.

25. Lower Colorado Water Supply Report, Bureau of Reclamation, 6 December 2021. Available online: https://www.usbr.gov/lc/ region/g4000/weekly.pdf (accessed on 9 December 2021).

26. US Bureau of Reclamation Lake Powell—Storage. Available online: https://www.usbr.gov/uc/water/hydrodata/reservoir_ data/919/dashboard.html\#storage (accessed on 25 September 2021).

27. Wheeler, K.G.; Rosenberg, D.E.; Schmidt, J.C. Water Resource Modeling of the Colorado River: Present and Future Strategies. White Pap. 2019, 2. Available online: https:/ / docplayer.net/150092693-Water-resource-modelling-of-the-colorado-river-presentand-future-strategies.html (accessed on 13 December 2021).

28. Schmidt, J.; Kraft, M.; Tuzlak, D.; Walker, A. Fill Mead First: A Technical Assessment. White Pap. No. 1 2016. Available online: https:/ / qcnr.usu.edu/coloradoriver/files/CCRS_White_Paper_1.pdf (accessed on 13 December 2021).

29. US Bureau of Reclamation Colorado River Accounting and Water Use Report: Arizona, California, and Nevada, Editions 2011-2020. Available online: https:/ / www.usbr.gov/lc/region/g4000/wtracct.html (accessed on 25 September 2021).

30. US Bureau of Reclamation Colorado River Consumptive Uses and Losses Reports. Available online: https://www.usbr.gov/uc/ envdocs/plans.html\#ACULR (accessed on 25 September 2021). 
31. Bruce, B.; Prairie, J.; Maupin, M.A.; Dodds, J.; Eckhardt, D.; Ivahnenko, T.I.; Matuska, P.; Evenson, E.; Harrison, A. Comparison of US Geological Survey and Bureau of Reclamation Water-Use Reporting in the Colorado River Basin; US Geological Survey: Reston, VA, USA, 2018. Available online: https://pubs.usgs.gov/sir/2018/5021/sir20185021.pdf (accessed on 13 December 2021).

32. US Bureau of Reclamation 5-Year Probabilistic Projections. Available online: https://www.usbr.gov/lc/region/g4000/riverops/ crss-5year-projections.html (accessed on 13 December 2021).

33. Cordalis, A.; Cordalis, D. Indian Water Rights: How Arizona v. California Left an Unwanted Cloud over the Colorado River Basin. Ariz J. Env. Law Policy 2014, 5, 333-362.

34. US Bureau of Reclamation Colorado River Basin Water Supply and Demand Study. 2012. Available online: https://www.usbr. gov/lc/region/programs/crbstudy.html (accessed on 13 December 2021).

35. Power Consulting. The Impact of Loss of Electric Generation at Glen Canyon Dam. 2015. Available online: http://www. powereconconsulting.com/WP/assets/Full-Study_Power-Economic-Consulting_7_26_2016.pdf (accessed on 13 December 2021).

36. Runyon, L. Hydropower Worries Grow As Colorado River Reservoirs Keep Dropping. Available online: https://www.kunc.org/ environment/2021-07-13/hydropower-worries-grow-as-colorado-river-reservoirs-keep-dropping (accessed on 25 September 2021).

37. Jones, B.A.; Berrens, R.P.; Jenkins-Smith, H.C.; Silva, C.L.; Carlson, D.E.; Ripberger, J.T.; Gupta, K.; Carlson, N. Valuation in the Anthropocene: Exploring Options for Alternative Operations of the Glen Canyon Dam. Water Resour. Econ. 2016, 14, 13-30. [CrossRef]

38. Smith, J. Electric Costs in Colorado Set to Surge as Lake Powell Struggles to Produce Hydropower. Water Educ. Colo. 2021. Available online: https: / / www.watereducationcolorado.org/fresh-water-news/electric-costs-in-colorado-set-to-surge-as-lakepowell-struggles-to-produce-hydropower/ (accessed on 13 December 2021).

39. Western Area Power Administration Notice of Rate Order Concerning Fixed Firm Power Rates. Available online: https: / /www.govinfo.gov/content/pkg/FR-2021-11-05/pdf/2021-24217.pdf (accessed on 13 December 2021).

40. Revelle, R.R.; Waggoner, P.E. Effects of a Carbon Dioxide-Induced Climatic Change on Water Supplies in the Western United States. In Changing Climate; National Academy Press: Washington, DC, USA, 1983; p. 496.

41. Milly, P.C.; Dunne, K.A. Colorado River Flow Dwindles as Warming-Driven Loss of Reflective Snow Energizes Evaporation. Science 2020, 367, 1252-1255. [CrossRef] [PubMed]

42. Lochhead, J.S. An Upper Basin Perspective on California's Claims to Water from the Colorado River Part II: The Development, Implementation and Collapse of California's Plan to Live Within Its Basic Apportionment. U Denv. Water Rev. $2002,6,318$.

43. Fleck, J. Water Is for Fighting over: And Other Myths about Water in the West; Island Press: Washington, DC, USA, 2016; ISBN 978-1-61091-679-0.

44. LaRue, E. Water Power and Flood Control of Colorado River Below Green River Utah, with a Foreword by Hubert Work, Secretary of the Interior; US Government Printing Office: Washington, DC, USA, 1925.

45. Ostrom, V.; Tiebout, C.M.; Warren, R. The Organization of Government in Metropolitan Areas: A Theoretical Inquiry. Am. Polit. Sci. Rev. 1961, 55, 831-842. [CrossRef]

46. Stephan, M.; Marshall, G.; McGinnis, M. An Introduction to Polycentricity and Governance. In Governing Complexity; Cambridge University Press: Cambridge, UK, 2019; pp. 21-44.

47. Gerlak, A.K.; Garrick, D.; Anderson, G.; Connell, D.; Pittock, J. Federalism and US Water Policy. In Federal Rivers: Managing Water in Multi-Layered Political Systems; Edward Elgar: Cheltenham, UK, 2014; pp. 41-56.

48. Karambelkar, S.; Gerlak, A.K. Collaborative Governance and Stakeholder Participation in the Colorado River Basin. Nat. Resour. J. 2020, 60, 47.

49. Ostrom, E. Collective Action and the Evolution of Social Norms. J. Econ. Perspect. 2000, 14, 137-158. [CrossRef]

50. US Bureau of Reclamation Water Operations | Upper Colorado Basin I Bureau of Reclamation. Available online: https: //www.usbr.gov/uc/water/index.html (accessed on 17 October 2021).

51. US Bureau of Reclamation Lower Colorado River Operations | Lower Colorado Region | Bureau of Reclamation. Available online: https:/ / www.usbr.gov/lc/ riverops.html (accessed on 17 October 2021).

52. US Bureau of Reclamation Colorado River Natural Flow and Salt Data. Available online: https://www.usbr.gov/lc/region/g400 0/NaturalFlow/current.html (accessed on 17 October 2021).

53. Maupin, M.A.; Ivahnenko, T.I.; Bruce, B. Estimates of Water Use and Trends in the Colorado River Basin, Southwestern United States, 1985-2010; No. 2018-5049; US Geological Survey: Reston, VA, USA, 2018. Available online: https://pubs.usgs.gov/sir/2018/504 9/sir20185049.pdf (accessed on 13 December 2021).

54. Moore, S. Toward Effective River Basin Management (RBM): The Politics of Cooperation, Sustainability, and Collaboration in the Delaware River Basin. J. Environ. Manag. 2021, 298, 113421. [CrossRef]

55. Robison, J.A.; Kenney, D.S. Equity and the Colorado River Compact. Environ. Law 2012, 1157-1209.

56. Richter, B.D.; Benoit, K.; Dugan, J.; Getacho, G.; LaRoe, N.; Moro, B.; Rynne, T.; Tahamtani, M.; Townsend, A. Decoupling Urban Water Use and Growth in Response to Water Scarcity. Water 2020, 12, 2868. [CrossRef]

57. Koebele, E.A. When Multiple Streams Make a River: Analyzing Collaborative Policymaking Institutions Using the Multiple Streams Framework. Policy Sci. 2021, 54, 1-20. [CrossRef]

58. Department of the Interior Record of Decision, Colorado River Interim Surplus Guidelines Final Environmental Impact Statement 2001. Available online: https://www.usbr.gov/lc/region/g4000/surplus/surplus_rod_final.pdf (accessed on 13 December 2021). 
59. Las Vegas Sun Norton Threatens Water Shutoff. Available online: https://lasvegassun.com/news/2002/dec/17/nortonthreatens-water-shutoff/ (accessed on 25 September 2021).

60. Department of the Interior Colorado River Water Delivery Agreement. Available online: https://www.usbr.gov/lc/region/g400 0/crwda/crwda.pdf (accessed on 25 September 2021).

61. Department of the Interior Record of Decision: Colorado River Interim Guidelines for Lower Basin Shortages and the Coordinated Operations for Lake Powell and Lake Mead 2007. Available online: https: / www.usbr.gov/lc/region/programs/strategies / RecordofDecision.pdf (accessed on 13 December 2021).

62. Osias, D.; Hicks, T. 43 CFR Part 417 Does Not Authorize Federal Agency Adjudication of IID Beneficial Use of Colorado River Water. Hastings W-Nw. J. Envtl. Pol. 2008, 14, 1499.

63. Utilization of the Waters of the Colorado and Tijuana Rivers and of the Rio Grande, Treaty between the United States of America and Mexico 1946. Available online: https:/ / www.ibwc.gov / Files/1944Treaty.pdf (accessed on 13 December 2021).

64. DeMarsay, A. The Brownell Task Force and the Mexican Salinity Problem; Colorado River Basin Salinity Control Forum: Bountiful, UT, USA, 1991; Available online: https: / / www.coloradoriversalinity.org/docs/The\%20Brownell\%20Task $\% 20$ Force $\% 20$ and $\% 20$ the $\%$ 20Mexican\%20Salinity\%20Problem,\%20A\%20Narrative\%20Chronology\%20of\%20Events.pdf (accessed on 13 December 2021).

65. Brownell, H.; Eaton, S.D. The Colorado River Salinity Problem with Mexico. Am. J. Int. Law 1975, 69, 255-271. [CrossRef]

66. US Department of State, Office of Historian Foreign Relations of the United States, 1969-1976, Volume E-10, Documents on American Republics, 1969-1972-Office of the Historian. Available online: https://history.state.gov/historicaldocuments/frus1 969-76ve10/d461 (accessed on 25 September 2021).

67. International Boundary and Water Commission Minute No. 242, Permanent and Definitive Solution to the International Problem of Salinity of the Colorado River. Available online: https:/ / www.ibwc.gov/Files/Minutes/Min242.pdf (accessed on 25 September 2021).

68. International Boundary and Water Commission Minute 318: Adjustment of Delivery Schedules for Water Allotted to Mexico for the Years 2010 Through 2013 as a Result of Infrastructure Damage in Irrigation District 014, Rio Colorado, Caused by the April 2010 Earthquake in the Mexicali Valley, Baja California. Available online: https://www.ibwc.gov/Files/Minutes/Min_318.pdf (accessed on 25 September 2021).

69. King, J.S.; Culp, P.W.; de la Parra, C. Getting to the Right Side of the River: Lessons for Binational Cooperation on the Road to Minute 319. U Denv. Water Rev. 2014, 18, 36.

70. Jewell, S. Remarks of Interior Secretary Sally Jewell. Available online: http://www.crwua.org/assets/downloads/2013-annualconference/CRWUA_2013_Annual_Conference_-_Sally_Jewell_Dec._11-13_2013.pdf (accessed on 25 September 2021).

71. US Bureau of Reclamation Lake Mead Annual High and Low Elevations (1935-2020). Available online: https://www.usbr.gov / lc/region/g4000/lakemead_line.pdf (accessed on 27 September 2021).

72. Sullivan, A.; White, D.D.; Hanemann, M. Designing Collaborative Governance: Insights from the Drought Contingency Planning Process for the Lower Colorado River Basin. Environ. Sci. Policy 2019, 91, 39-49. [CrossRef]

73. Burman, B. Remarks Delivered By: Brenda Burman, Commissioner 2018 Colorado River Water Users Association Annual Convention 13 December 2018. Available online: http:/ / www.crwua.org/assets/downloads/2018-annual-conference/CommissionerBurman-CRWUA-Speech-2018-12-13.pdf (accessed on 25 September 2021).

74. US Bureau of Reclamation Agreement Concerning Colorado River Drought Contingency Management and Operations. Available online: https:/ / www.usbr.gov/dcp/docs/final/Companion-Agreement-Final.pdf (accessed on 25 September 2021).

75. Agreement among US, Arizona, Reclamation, Central Arizona Water Conservation District, and Colorado River Indian Tribes. Available online: https://new.azwater.gov/sites/default/files/media/Exhibit6.1.1_US_ADWR_CAWCD_CRIT_Agreement_ System_Conservation.pdf. (accessed on 13 December 2021).

76. Intergovernmental Agreement between Arizona Water Banking Authority and Gila River Indian Community. Available online: https:/ / waterbank.az.gov/sites/default/files/ICS\%20Firming\%20Credit\%20IGA\%20executed.pdf (accessed on 25 September 2021).

77. Buschatzke, T. The DCP Makes CO River Delivery Shortfalls Less Painful, but It Doesn't Make Them Go Away I Arizona Department of Water Resources. Available online: https:/ / new.azwater.gov/news/articles/2018-05-09 (accessed on 25 September 2021).

78. US Bureau of Reclamation News Archive: Reclamation Announces 2021 Colorado River Operating Conditions. Available online: https://www.usbr.gov/newsroom/newsroomold/newsrelease/detail.cfm?RecordID=72085 (accessed on 25 September 2021).

79. Runyon, L. Colorado River Basin Reservoirs Begin Emergency Releases To Prop Up A Troubled Lake Powell. Available online: https: / www.kunc.org/environment/2021-07-15/colorado-river-basin-reservoirs-begin-emergency-releases-to-propup-a-troubled-lake-powell (accessed on 25 September 2021).

80. Fonseca, F. California Dispute Threatens Plan to Protect Colorado River. Available online: https://apnews.com/article/fc500d0 5bb5243ee99d72b3f9fe89df0 (accessed on 25 September 2021).

81. Pitzer, G. As Colorado River Levels Drop, Pressure Grows On Arizona To Complete A Plan for Water Shortages. Available online: https: / / www.watereducation.org/western-water/colorado-river-levels-drop-pressure-grows-arizona-complete-planwater-shortages (accessed on 25 September 2021).

82. James, I. Colorado River Drought: Dispute Puts Arizona Piece of Deal in Jeopardy. Available online: https://www.azcentral.com/ story/news/local/arizona-environment/2019/02/15/colorado-river-drought-dispute-puts-arizona-deal-gila-river-indiancommunity/2875312002/ (accessed on 25 September 2021). 
83. US Bureau of Reclamation Agreement Regarding Storage at Colorado River Storage Project Act Reservoirs under an Upper Basin Demand Management Program. Available online: https://www.usbr.gov/lc/region/g4000/dcpdocs/Attachment-A2-DemandManagment-Storage-Agreement-Final.pdf (accessed on 27 September 2021).

84. Kenney, D. Making the Case for a Grand Bargain, Colorado River District 2019 Annual Seminar. Available online: https: //www.coloradoriverdistrict.org/annual-seminars/ (accessed on 26 September 2021).

85. MacDonnell, L. Sources of Controversy in the Law of the Colorado River: An Upper Basin View. Available SSRN 3874212.2021. Available online: https:/ / papers.ssrn.com/sol3/papers.cfm?abstract_id=3874212 (accessed on 13 December 2021). 